\title{
Pharmacologic agents for smoking cessation: A clinical review
}

\section{Dilip R Patel' \\ Cynthia Feucht ${ }^{2}$ \\ Lesley Reid' \\ Neil D Patel'}

'Michigan State University, Kalamazoo Center for Medical Studies, Kalamazoo, MI, USA; ${ }^{2}$ Ferris State University College of Pharmacy, Kalamazoo, MI, USA
Correspondence: Dilip R Patel Michigan State University, Kalamazoo Center for Medical Studies, I000, Oakland Drive, Kalamazoo, MI 49008, USA

Tel +l 2693376450

Fax +I 2693376475

Email patel@kcms.msu.edu
This article was published in the following Dove Press journal:

Clinical Pharmacology:Advances and Applications

2 April 2010

Number of times this article has been viewed

\begin{abstract}
Tobacco use has been clearly demonstrated to have negative health consequences. Smoking cigarettes is the predominant method of tobacco use. The tar contained within cigarettes and other similar products is also harmful. Other tarless tobacco containing products do exist but carry no significantly decreased risk. While nicotine is considered to be principally responsible for tobacco addiction, other chemicals in the cigarette smoke including acetaldehyde may contribute to the addictive properties of tobacco products. The adverse health consequences of tobacco use have been well documented. Studies have shown that a combined behavioral and pharmacological approach is more effective in smoking cessation than either approach alone. Pharmacotherapy can achieve $50 \%$ reduction in smoking. With pharmacotherapy the estimated 6-month abstinence rate is about $20 \%$, whereas it is about $10 \%$ without pharmacotherapy. The first-line of drugs for smoking cessation are varenicline, bupropion sustained release, and nicotine replacement drugs, which are approved for use in adults. Data are insufficient to recommend their use in adolescents. This article reviews the use of pharmacological agents used for smoking cessation. A brief overview of epidemiology, chemistry, and adverse health effects of smoking is provided.
\end{abstract}

Keywords: smoking, tobacco, nicotine, nicotine addiction, varenicline, bupropion sustained release, nicotine replacement therapy, electronic cigarettes

\section{Introduction}

The tobacco plant is native to South America, Mexico, and the West Indies. ${ }^{1}$ The American Indians used various forms of tobacco for its medicinal properties for hundreds of years before the discovery of the New World by Christopher Columbus. ${ }^{1}$ The common tobacco, Nicotiana tabacum, is named after Jean Nicot, the French ambassador to Lisbon, who is believed to have sent its seeds to Catherine de Medicis, the queen consort and regent of France in $1566 .{ }^{1}$ Nicotine was first extracted in its crude form in 1571, purified form in 1928, and synthesized in a laboratory in 1904. ${ }^{1}$ Over the decades, the causative role of smoking, and other forms of tobacco use, in cancer has been well-established. This article reviews the pharmacological agents currently used for smoking cessation. These include the various forms of nicotine replacement products, varenicline, bupropion sustained release, nortriptyline, and clonidine. A brief overview of the epidemiology of smoking, the chemistry and pharmacology of nicotine, and adverse health consequences of smoking is provided as a background to better understand the use of pharmacological agents for smoking cessation. 


\section{Epidemiology}

Cigarette smoking is the most popular method of using tobacco; other forms of smoking and tobacco use are summarized in Table $1 .^{2-4}$ Worldwide, tobacco use causes more than 5 million deaths per year and if the current trends in the use of tobacco continue, it will cause 8 million deaths per year by $2030 .{ }^{5}$ Cigarette smoking is the leading preventable cause of death in the United States, responsible for about one in five or half-million deaths every year. ${ }^{4}$ Exposure to environmental tobacco smoke (ETS) results in an estimated 49,000 deaths every year. ${ }^{2}$ Smoking and use of other forms of tobacco by youth is of particular significance, with $60 \%$ of new smokers being under the age of 18 when they first smoked a cigarette.

In 2007, more than 3 million American adolescents (aged 12-17) reported using a tobacco product in the month prior to the survey. ${ }^{2}$ Tobacco use by adolescents is influenced by multiple psychosocial and biological factors that increase adolescents' vulnerability for nicotine use. ${ }^{2,6,7}$ Studies show that adolescents are more sensitive to the reinforcing effects of nicotine and other chemicals found in cigarettes, further increasing their susceptibility to tobacco addiction. Intermittent smoking, such as over the weekends or at parties, has also been shown to result in tobacco addiction in adolescents. Tobacco use, especially the smokeless forms, is of special concern in athletes. ${ }^{8-15}$

Electronic cigarettes are a new trend and a major concern for young smokers. ${ }^{16,17}$ Electronic cigarettes are marketed to young smokers and are easily available over the internet and in shopping malls. The labeling on these cigarettes does not include the United States Food and Drug Administration (US FDA) warning of its harmful effects. ${ }^{16}$ Also called e-cigarettes, these are battery-operated devices that generally contain cartridges filled with nicotine, flavor and other chemicals. The electronic cigarette turns nicotine and other chemicals into vapor that is inhaled by the user. The US FDA has found that this form of cigarette is equally harmful, toxic, and addictive as other forms of tobacco use. ${ }^{16,17}$ In addition to various carcinogens, e-cigarettes also contain other chemicals such as diethylene glycol, which is an ingredient found in antifreeze liquid. ${ }^{16}$

\section{Chemistry and pharmacology}

Approximately 4,000 chemicals are found in the smoke of tobacco products, of which nicotine is primarily responsible for tobacco addiction. ${ }^{2,6,7}$ The chemistry and neuropharmacology of nicotine has been extensively studied. ${ }^{18-21}$ Other

Table I Main forms of tobacco used

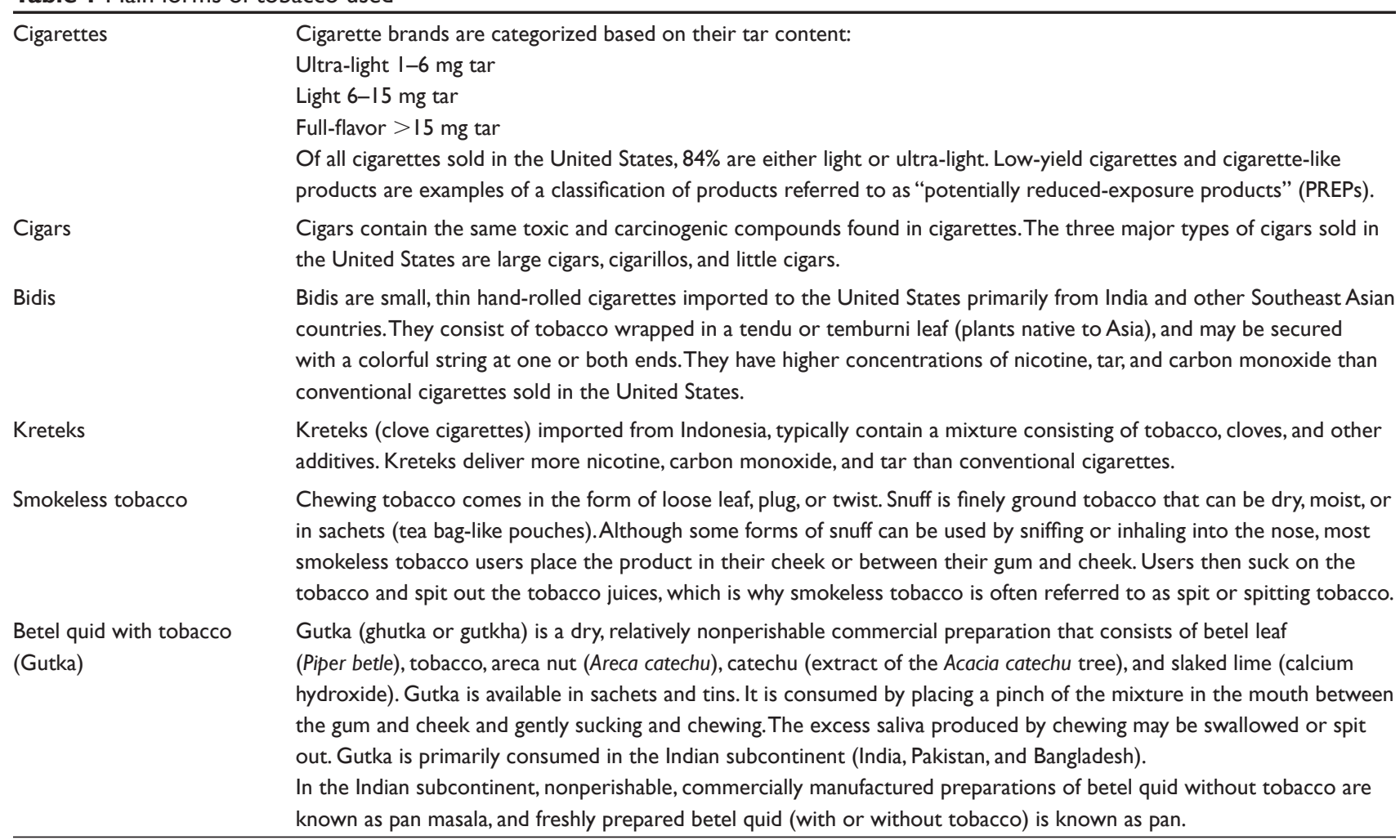

Based on data from: Centers for Disease Control and Prevention. Smoking and tobacco use: fact sheets. Available at http://www.cdc.gov/tobacco/data_statistics/fact_sheets. Accessed August II, 2009. 
main constituents of smoke that result in adverse health consequences include ammonia, benzene, carbon monoxide, cyanide, formaldehyde, acetaldehyde, phenols, and tar. Approximately $90 \%$ of the constituents of the smoke are in the form of vaporized chemicals, while rest are in the particulate form. ${ }^{2,4,22}$

Cigarettes are categorized (Table 1) based on their tar content (total particulate matter in smoke, excluding water and alkaloid compounds), which is measured using a standardized protocol on a smoking machine. ${ }^{2-4}$ In filtered cigarettes $(99 \%$ of cigarettes currently on the market), the filter vents dilute the smoke with air, reducing standard yields of tar, nicotine, and carbon monoxide. Many smokers block the vents or compensate with increased inhalations when smoking lowyield cigarettes. By doing so, they typically get as much tar and nicotine from cigarettes with low-yield ratings as those with higher yields. On average a cigarette contains between 13-19 mg of nicotine; smoking 1 cigarette typically delivers 1-2 mg of nicotine. ${ }^{2,6,7}$ The nicotine content of tobacco smoke is $1 \%-2 \%$ and each inhalation delivers approximately $0.05-0.15 \mathrm{mg}^{2,7}$

Smoke is produced by the incomplete combustion of tobacco. The fate of the cigarette smoke is depicted in Figure 1.22 Mainstream smoke-the smoke inhaled by the smoker directly through the mouthpiece of the cigarette-constitutes approximately $45 \%$ of the total smoke; whereas side stream smoke, which is the smoke emitted by smoldering tobacco between puffs and the smoke diffusing through the lit cigarette paper and escaping from the burning cone during smoking, constitutes $55 \%$ of the total smoke. ${ }^{22}$

Nicotine, whose chemical structure resembles that of the neurotransmitter acetylcholine, acts on stereospecific nicotinic cholinergic receptors (nAChRs) in the brain and other organs. ${ }^{7,21}$ The chemical structure and metabolic pathway of nicotine is depicted in Figure 2. It also has both direct and indirect effects on the neuroendocrine system. The initial phase of stimulation of the central nervous system (CNS) by nicotine is typically followed by a phase of CNS depression. ${ }^{7,20}$ The action of nicotine on nAChRs stimulates the release of various neurotransmitters and hormones including acetylcholine, norepinephrine, dopamine, vasopressin, serotonin, and beta-endorphins. ${ }^{2,67,19}$ Research shows that smoking is associated with a marked decrease in monoamine oxidase (MAO) levels in the brain. ${ }^{7}$ It is postulated that this decrease in $\mathrm{MAO}$ is caused by chemicals in the smoke other than nicotine. Decreased levels of MAO-A and MAO-B in the brain result in a higher level of dopamine. The action of nicotine on the CNS increases alertness, improves memory, improves concentration, and decreases anxiety. The pharmacokinetic properties of nicotine are summarized in Table 2 . $^{2,4,7,8,21}$

\section{Effects on health}

The wide-ranging adverse effects of tobacco use have been well-established and well-documented. 2,4,6,22-28 The numerous harmful health consequences of smoking are summarized in Table 3.

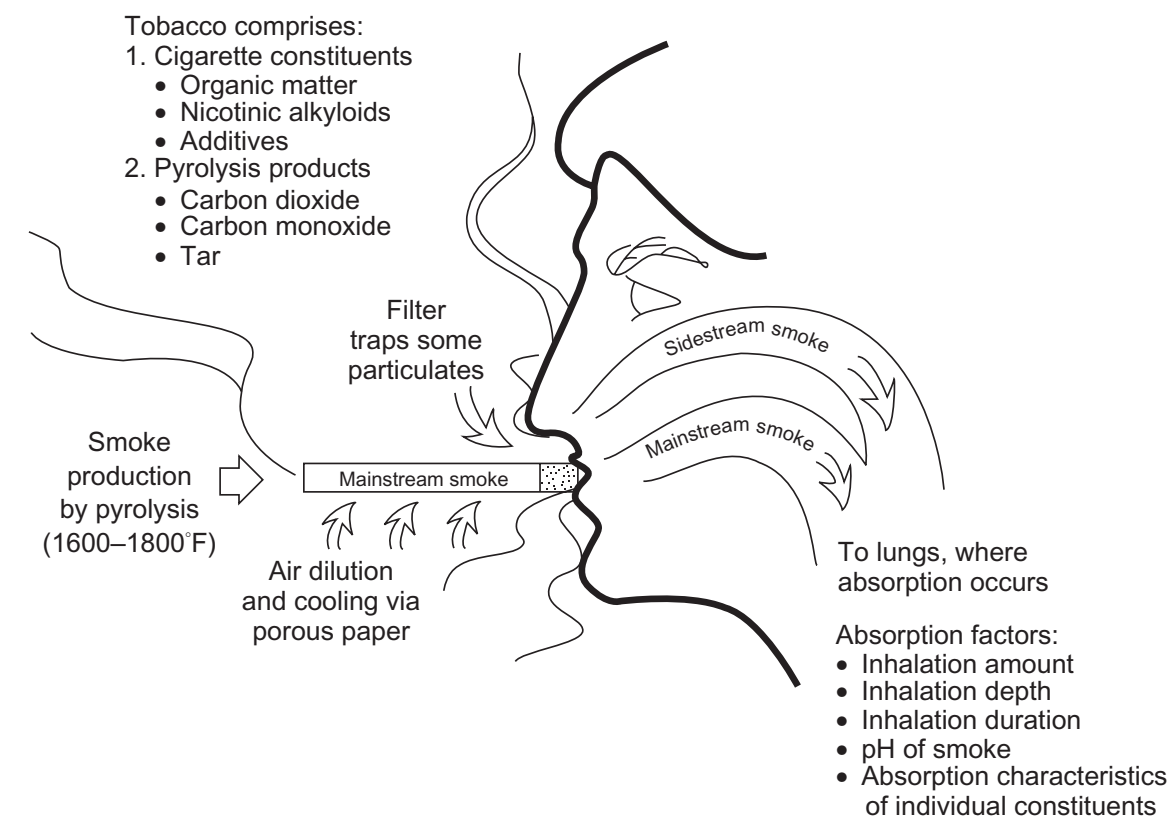

Figure I Fate of cigarette smoke.

From: US Department of Health and Human Services:The Health Consequences of Smoking. Nicotine Addiction:A Report of the Surgeon General.Washington, DC, 1988. 


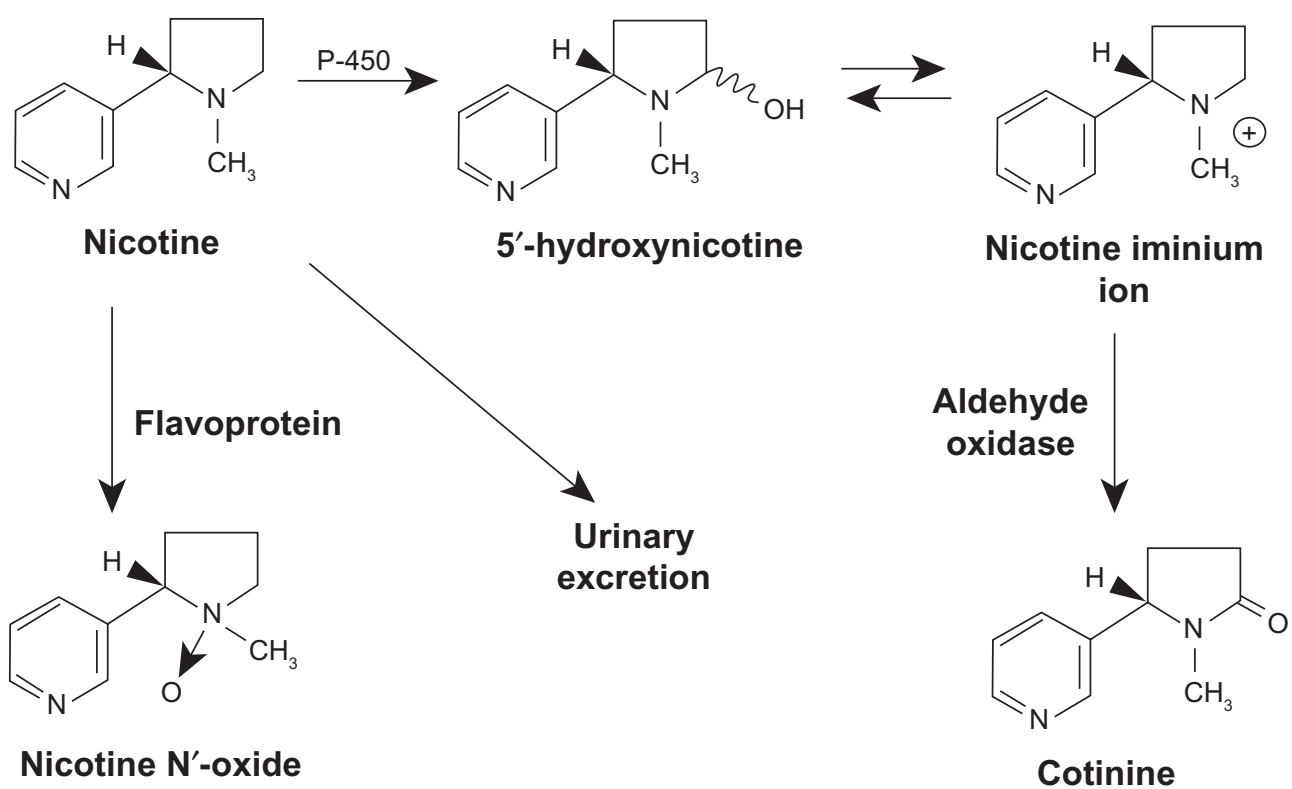

Figure 2 Chemical structure and metabolic pathway of nicotine.

From: US Department of Health and Human Services:The Health Consequences of Smoking. Nicotine Addiction:A Report of the Surgeon General.Washington, DC, 1988.

Nicotine activates reward pathways in the brain that regulate feelings of pleasure. ${ }^{7}$ These effects of nicotine are mediated by dopamine. Nicotine increases levels of dopamine mainly by its action on the mesolimbic dopamine system. ${ }^{7,21}$ Chronic use of nicotine results in an increase in the number of nicotine receptors in the brain. ${ }^{6,7,19}$ Consequently, more nicotine is required to achieve the desired effect, eventually resulting in tolerance and dependence. Regular tobacco use results in nicotine accumulation in the body, exposing the user to the effects of nicotine throughout the 24 hours. Nicotine

Table 2 Pharmacokinetics of nicotine ${ }^{2,4,7,8,21}$

\begin{tabular}{|c|c|}
\hline Absorption & $\begin{array}{l}\text { - } 10 \%-50 \% \text { of available nicotine is absorbed during } \\
\text { puffing; } 80 \% \text { during deep inhalation } \\
\text { - Readily and completely absorbed via mucous } \\
\text { membranes and skin }\end{array}$ \\
\hline Distribution & $\begin{array}{l}\text { - Readily distributed in all body tissues } \\
\text { - Reaches brain within } 10 \mathrm{~s} \\
\text { - Acute spike in arterial nicotine level occurs } \\
\text { - Steady state volume of distribution is } \\
\text { approximately } 2.6 \text { times the body weight in } \mathrm{kg}\end{array}$ \\
\hline Metabolism & $\begin{array}{l}\text { - } 80 \% \text { is metabolized in the liver to continine } \\
\text { by enzyme CYP2A6 (and to a lesser extent by } \\
\text { CYP2B6 and CYP2EI) } \\
\text { - Rest is metabolized in the lungs and kidneys }\end{array}$ \\
\hline Elimination & $\begin{array}{l}\text { - Average elimination half-life is } 2 \mathrm{~h} \\
\text { - Average elimination half-life of nicotine metabolite } \\
\text { cotinine is } 16 \mathrm{~h} \\
\text { - Cotinine is not detectable in urine after complete } \\
\text { abstinence of I wk } \\
\text { - Unaltered nicotine and its metabolites excreted } \\
\text { by kidneys }\end{array}$ \\
\hline
\end{tabular}

levels in the brain and the associated feelings of pleasure and reward peak within 10 seconds of inhalation., ${ }^{2,47}$ However, the acute effects of nicotine dissipate rapidly. This causes the smoker to continue to smoke to maintain the effects of the nicotine and prevent withdrawal symptoms. The significant neurochemical changes in the brain that result from chronic nicotine use make it very difficult for the smoker to quit. Animal studies have shown that acetaldehyde, a chemical found in tobacco smoke, dramatically increases the reinforcing properties of nicotine and may also contribute to tobacco addiction. ${ }^{2,47}$ Adolescent animals show far more sensitivity to this reinforcing effect, suggesting increased vulnerability of adolescents to tobacco addiction.

Abrupt cessation of smoking results in withdrawal symptoms primarily due to decreased nicotine levels. Symptoms of nicotine withdrawal include: irritability; craving; depression; anxiety; cognitive and attention deficits; sleep disturbances; and increased appetite. ${ }^{6,22}$ The withdrawal symptoms, in most cases, begin within a few hours after the last cigarette, peak within the first few days of smoking cessation, and usually subside within a few weeks. In some cases, however the symptoms may persist for months. ${ }^{4,6}$

\section{The role of behavioral approaches to smoking cessation}

Behavioral treatment is integral to smoking cessation-studies have shown that a combination of behavioral and pharmacological treatment is more effective than either approach 
Table 3 Adverse health effects of smoking and tobacco use

\begin{tabular}{|c|c|}
\hline Disease & \\
\hline Cancer & $\begin{array}{l}\text { - Bladder cancer } \\
\text { - Cervical cancer } \\
\text { - Esophageal cancer } \\
\text { - Kidney cancer } \\
\text { - Laryngeal cancer } \\
\text { - Leukemia } \\
\text { - Lung cancer } \\
\text { - Oral cancer } \\
\text { - Pancreatic cancer } \\
\text { - Stomach cancer }\end{array}$ \\
\hline Cardiovascular diseases & $\begin{array}{l}\text { - Abdominal aortic aneurysm } \\
\text { - Acute and episodic increase in blood } \\
\text { pressure } \\
\text { - Acute increase in peripheral vascular } \\
\text { resistance and blood pressure } \\
\text { - Atherosclerosis } \\
\text { - Cerebrovascular disease } \\
\text { - Coronary heart disease } \\
\text { - Decreased coronary blood flow (due } \\
\text { to constriction of coronary arteries) } \\
\text { - Decreased oxygen carrying capacity } \\
\text { of the hemoglobin } \\
\text { - Hypertension } \\
\text { - Increased baseline heart rate } \\
\text { - Increased oxygen demands of the } \\
\text { myocardium (due to increased heart } \\
\text { rate and blood pressure) } \\
\text { - Increased risk for thromboembolism } \\
\text { - Increased risk of ventricular } \\
\text { arrhythmias and sudden death (due } \\
\text { to increased platelet adhesiveness, } \\
\text { releasing catecholamines causing } \\
\text { acute thrombosis and promoting } \\
\text { ventricular arrhythmias) } \\
\text { - Peripheral vascular disease }\end{array}$ \\
\hline Respiratory diseases & $\begin{array}{l}\text { - Bronchiolitis } \\
\text { - Bronchitis } \\
\text { - Chronic cough } \\
\text { - Chronic obstructive pulmonary } \\
\text { disease } \\
\text { - Decreased forced expiratory volume } \\
\left(F_{1}\right) \\
\text { - Decreased peak expiratory flow rate } \\
\text { (PEFR) } \\
\text { - Development and exacerbation of } \\
\text { asthma } \\
\text { - Dyspnea } \\
\text { - Eosinophilic granuloma } \\
\text { - Halitosis } \\
\text { - Hoarseness } \\
\text { - Idiopathic pulmonary fibrosis } \\
\text { - Impaired lung growth } \\
\text { - Impaired respiratory immunity } \\
\text { - Increased respiratory allergies } \\
\text { - Interstitial lung disease } \\
\text { - Laryngitis } \\
\text { - Otitis media and middle ear effusions }\end{array}$ \\
\hline
\end{tabular}

Table 3 (Continued)

\begin{tabular}{|c|c|}
\hline \multicolumn{2}{|l|}{ Disease } \\
\hline & - Pneumonia \\
\hline & - Pulmonary hemorrhage \\
\hline & - Pulmonary hypertension \\
\hline & - Rhinitis \\
\hline & - Sinusitis \\
\hline & - Snoring \\
\hline & - Spontaneous pneumothorax \\
\hline & - Upper respiratory infections \\
\hline \multirow[t]{5}{*}{ Reproductive effects } & - Fertility \\
\hline & - Fetal death and stillbirths \\
\hline & - Low birth weight \\
\hline & - Pregnancy complications \\
\hline & - Premature menopause \\
\hline \multirow[t]{3}{*}{ Musculoskeletal } & - Decreased bone mineral density \\
\hline & - Increased risk for fractures \\
\hline & - Increased spinal disk disease \\
\hline \multirow[t]{5}{*}{ Gastrointestinal } & - Decreased appetite \\
\hline & - Gastroesophageal reflux disease \\
\hline & - Impaired glucose tolerance \\
\hline & - Increase insulin resistance \\
\hline & - Peptic ulcer disease \\
\hline Mental health and & - Addiction \\
\hline \multirow[t]{4}{*}{ psychosocial } & - Anxiety, palpitations, tremors \\
\hline & - Nervousness, depression \\
\hline & - Tolerance and dependence \\
\hline & -Withdrawal symptoms \\
\hline \multirow{9}{*}{$\begin{array}{l}\text { Effects on offspring } \\
\text { of maternal smoking } \\
\text { during pregnancy }\end{array}$} & - Certain childhood cancers \\
\hline & - Increased cotinine in breastfed infants \\
\hline & if mother smokes \\
\hline & $\begin{array}{l}\text { - Increased incidence of conduct } \\
\text { disorders }\end{array}$ \\
\hline & $\begin{array}{l}\text { - Increased probability of female chil- } \\
\text { dren to be smokers }\end{array}$ \\
\hline & - Low birth weight \\
\hline & - Miscarriage \\
\hline & - Prematurity \\
\hline & - Sudden infant death syndrome \\
\hline \multirow{7}{*}{$\begin{array}{l}\text { Specific effects of } \\
\text { smokeless tobacco use }\end{array}$} & - Excess salivation \\
\hline & - Gingivitis, gingival recession \\
\hline & - Halitosis \\
\hline & - Leukoplakia \\
\hline & - Oropharyngeal cancers \\
\hline & - Periodontal disease \\
\hline & - Staining of teeth \\
\hline \multirow[t]{10}{*}{ Other effects } & - Altered lipid profile \\
\hline & $\begin{array}{l}\text { - Altered metabolism of therapeutic } \\
\text { drugs }\end{array}$ \\
\hline & - Anorexia and weight loss \\
\hline & - Cataracts \\
\hline & - Decreased exercise performance \\
\hline & $\begin{array}{l}\text { - Diminished health status/increased } \\
\text { morbidity }\end{array}$ \\
\hline & - Esophagitis \\
\hline & - Gastroesophageal reflux disease \\
\hline & - Hip fractures \\
\hline & - Low bone density \\
\hline
\end{tabular}

(Continued) 
Table 3 (Continued)

\begin{tabular}{ll}
\hline Disease & \\
\hline & Macular degeneration \\
- Nicotine addiction (tolerance & dependence, withdrawal symptoms) \\
- Osteoporosis \\
- Peptic ulcer disease \\
- Spinal disk disease \\
\hline
\end{tabular}

Sources: U.S. Department of Health Education, and Welfare 1964, 1967, 1979; U.S. Department of Health and Human Services 1980, 1982, 1983, 1984, 1989, 1990, 1994, 200I. Data from: (I) U.S. Department of Health and Human Services: The Health Consequences of Smoking. Nicotine Addiction: A Report of the Surgeon General. Washington, DC, 1988 U.S. Department of Health and Human Services; (2) The Health Consequences of Smoking:A Report of the Surgeon General.Atlanta, GA: U.S. Department of Health and Human Services, CDC, National Center for Chronic Disease Prevention and Health Promotion, Office of Smoking and Health, 2004. Available at http://www.cdc,gov/tobacco/data_statistics/sgr_2004/index.htm. Accessed August II, 2009.

alone ${ }^{3,29-32}$ Fiore and colleagues provide an extensive analysis of scientific evidence supporting the optimal efficacy of the combined behavioral and pharmacological approach for smoking cessation. The results of their meta-analysis of published studies indicate that providing counseling in addition to medication significantly enhanced treatment outcome - for medication alone the odds ratio $(95 \%$ confidence interval $[\mathrm{CI}])$ was 1.0 , and estimated abstinence rate $(95 \% \mathrm{CI})$ was 21.7, whereas for medication and counseling the estimated odds ratio $(95 \% \mathrm{CI})$ was $1.4(1.2-1.6)$, and estimated abstinence rate $(95 \% \mathrm{CI})$ was $27.6(25.0-30.3){ }^{3}$ Conversely, Fiore and colleagues also found that providing medication in addition to counseling also significantly enhanced treatment outcome - for counseling alone the estimated odds ratio (95\% CI) was 1 , and estimated abstinence rate $(95 \% \mathrm{CI})$ was 14.6 , whereas for medication and counseling the estimated odds ratio $(95 \% \mathrm{CI})$ was $1.7(1.3-2.1)$ and the estimated abstinence rate $(955 \mathrm{CI})$ was $22.1(18.1-26.8){ }^{3}$

In addition to the neurochemical effects of nicotine, behavioral factors also affect the severity of nictotine withdrawal symptoms. For some people, the feel, smell, and sight of a cigarette and the ritual of obtaining, handling, lighting, and smoking a cigarette are all associated with the pleasurable effects of smoking. Consequently, this can worsen withdrawal symptoms or cravings. Behavioral therapies can help smokers identify environmental triggers of craving so they can employ strategies to prevent or circumvent these symptoms and urges. It is important to recognize that smoking cessation is a team effort. The social setting in which smoking occurs, the social culture of the smoker, and the support networks available to the smoker, all play critical role in the success of smoking cessation by the smoker. Among the professionals, the pharmacist plays a critical role in providing ongoing support, education, and counseling.

\section{Pharmacological agents}

General factors, which should to be considered when prescribing pharmacological agents for smoking cessation, are summarized in Table 4. Patients who smoke may be on therapeutic drugs for other chronic diseases. The effective dosages of these therapeutic drugs reflect the adjustments made because of concomitant exposure to nicotine. With smoking cessation and elimination of nicotine from the body, a new state of metabolic homeostasis will result that may necessitate adjusting dosage of therapeutic drugs. Drug-drug interactions are an important consideration when using pharmacotherapy for smoking cessation, especially in smokers who are on other medications for chronic diseases. Smoking induces some isoforms of the hepatic cytochrome P450. Nicotine, although metabolized by CYPP2A6, is not a significant inducer of CYP enzymes. ${ }^{3}$ Therefore, when smoker quits with or without being on nicotine replacement therapy, the baseline functioning of the P450 enzyme system is restored, and can increase the serum levels of certain drugs (eg, fluvoxamine, olanzepine, clozapine), resulting in their increased side-effects. ${ }^{3}$ Nicotine replacement therapy may reduce the sedative effects of benzodiazepines, subcutaneous absorption of insulin, and the blood pressure lowering effect of some beta-blockers. ${ }^{3}$ Some drugs reported to have significant interactions with bupropion include: cyclophosphamide; orphenadrine; tricyclic antidepressants; antipsychotics; certain antiarrhythmic drugs; certain beta-blockers; carbamazepine; phenytoin; phenobarbital; valproate; and cimetidine. ${ }^{3}$ Varenicline is not reported to have specific significant drug-drug interactions.

Tobacco dependence should be considered a chronic disease and as such its management requires on-going patient education, counseling, and use of medications as indicated. ${ }^{3}$ Relapses are common during smoking cessation and patients require long-term monitoring and treatment. Long-term pharmacotherapy, combination therapy, and re-use of drugs previously used (recycling) should be considered in relapse prevention and treatment. In some patients who are not able to quit completely, pharmacotherapy has been used to reduce smoking, with some achieving a 50\% reduction in smoking. ${ }^{3,7}$ With pharmacotherapy, the estimated 6-month abstinence rate is about $20 \%$, compared to approximately $10 \%$ without pharmacotherapy. ${ }^{3,6,7}$ All pharmacologic agents have been shown to be effective in smoking cessation with odds ratios between two and four when compared to placebo treatment. ${ }^{3,6}$ Absolute smoking cessation rates vary depending on the particular pharmacologic agent used and the intensity of concomitant counseling; rates vary in range from 5\% to $35 \% .{ }^{3,6,7}$ The smoker's 
Table 4 Factors to be considered in the use of smoking cessation drugs

\begin{tabular}{|c|c|}
\hline Practical considerations & $\begin{array}{l}\text { Health insurance coverage, out-of-pocket costs, likelihood of adherence, dentures when considering the gums, or } \\
\text { dermatitis when considering the patch. }\end{array}$ \\
\hline $\begin{array}{l}\text { Patient's prior experience } \\
\text { with a medication }\end{array}$ & $\begin{array}{l}\text { Prior successful experience (sustained abstinence with the medication) suggests that the medication may be helpful } \\
\text { to the patient in a subsequent quit attempt, especially if the patient found the medication to be tolerable and or easy } \\
\text { to use. However, it is difficult to draw firm conclusions from prior failure with a medication. }\end{array}$ \\
\hline Environmental factors & $\begin{array}{l}\text { Consider the importance of smoker's social setting, social culture, and support networks. These and other environ- } \\
\text { mental factors play important role in the success of any smoking cessation strategy. }\end{array}$ \\
\hline Heavy users or smokers & $\begin{array}{l}\text { The higher-dose preparations of nicotine gum, patch, and lozenge have been shown to be effective in highly } \\
\text { dependent smokers. Combination nicotine replacement therapy (NRT) may be particularly effective in suppressing } \\
\text { tobacco withdrawal symptoms. NRT combinations are especially helpful for highly dependent smokers or those with } \\
\text { a history of severe withdrawal. }\end{array}$ \\
\hline Light users or smokers & $\begin{array}{l}\text { Cessation medications generally not beneficial to light smokers. If NRT is used with light smokers, consider reducing } \\
\text { the dose of the medication. No adjustments are necessary when using bupropion SR or varenicline. }\end{array}$ \\
\hline Gender & $\begin{array}{l}\text { NRT can be effective with both sexes; however, evidence is mixed as to whether NRT is less effective in women than } \\
\text { men. This may encourage the clinician to consider use of another type of medication with women, such as bupropion } \\
\text { SR or varenicline. }\end{array}$ \\
\hline Weight gain concern & $\begin{array}{l}\text { Bupropion SR and nicotine replacement therapies, in particular 4-mg nicotine gum and 4-mg nicotine lozenge, } \\
\text { delay - but do not prevent - weight gain. }\end{array}$ \\
\hline Depression & $\begin{array}{l}\text { Bupropion SR and nortriptyline appear to be effective, but nicotine replacement medications also appear to help } \\
\text { individuals with a history of depression. }\end{array}$ \\
\hline $\begin{array}{l}\text { History of cardiovascular } \\
\text { disease }\end{array}$ & The nicotine patch has been demonstrated safe for patients with a history of cardiovascular disease. \\
\hline Long-term use & $\begin{array}{l}\text { Long-term use is helpful with smokers who report persistent withdrawal symptoms during the course of medications, } \\
\text { who have relapsed in the past after stopping medication, or who desire long-term therapy.A minority of individuals } \\
\text { who successfully quit smoking use ad libitum NRT medications (gum, nasal spray, inhaler) long-term. The use of these } \\
\text { medications for up to } 6 \text { months does not present a known health risk and developing dependence on medications is } \\
\text { uncommon. The FDA has approved the use of bupropion SR, varenicline, and some NRT medications for 6-month use. }\end{array}$ \\
\hline Combination therapy & $\begin{array}{l}\text { Combining the nicotine patch long-term ( }>14 \text { weeks) with nicotine gum or nicotine nasal spray, the nicotine patch } \\
\text { with the nicotine inhaler, or the nicotine patch with bupropion SR, increases long-term abstinence rates relative to } \\
\text { placebo treatments. Combining varenicline with NRT agents has been associated with higher rates of side effects } \\
\text { (eg, nausea, headaches). }\end{array}$ \\
\hline
\end{tabular}

Sources: Copyright @ 2008. Modified with permission from: Fiore MC, Jaen CR, Baker TB, et al. Treating Tobacco Use and Dependence 2008 Update. Clinical Practice Guideline. Rockville, MD: U.S. Department of Health and Human Services. Public Health Service, 2008.

likelihood of long-term abstinence doubles with the use of nicotine inhaler, nicotine lozenge, nicotine nasal spray, or nicotine patch. ${ }^{3}$ Smith and colleagues looked at comparative effectiveness of 5 smoking cessation pharmacotherapies in primary care clinics. They reported 6 month abstinence rates for the 5 active pharmacotherapies as follows: bupropion SR, 16.8\%; lozenge, 19.9\%; patch, 17.7\%; patch + lozenge, $26.9 \%$; and bupropion SR + lozenge, $29.9 \% .{ }^{29}$ In a recent study Garrison and Dugan reported a quit rate for varenicline that ranged from approximately $40 \%$ to $65 \%{ }^{31}$

The first-line drugs for smoking cessation approved by the US Food and Drug Administration (FDA) are varenicline, bupropion sustained release (SR), and nicotine replacement drugs., ${ }^{3,33-44}$ These drugs are approved by the FDA for use in adults. Data are insufficient to assess their efficacy in adolescents. ${ }^{3}$ Pharmacotherapy has not been shown to be effective in light smokers and in those who use smokeless tobacco.

\section{Varenicline}

Varenicline acts by selective binding at $\alpha 4 \beta 2$ neuronal nicotinic acetylcholine receptors, which results in agonist activity, while simultaneously preventing nicotine binding to $\alpha 4 \beta 2$ receptors. ${ }^{7,39-41}$ The FDA recommendation for varenicline product label includes a warning that serious neuropsychiatric symptoms have been reported in patients being treated with this drug. Varenicline, therefore, should preferably be avoided in persons who have a history of neuropsychiatric disorders. It is not uncommon for patients to experience feelings of depression, anxiety, irritability, and sleep disturbances during smoking cessation. Although some of these symptoms may be associated with nicotine withdrawal, symptoms have occurred in patients who continued to smoke. Patients on varenicline should be monitored for agitation, depressed mood, and changes in behavior that are not typical for the patient. The patient also must be assessed for suicidal ideation or suicidal behavior. Varenicline is 
reported to be well-tolerated for up to 1 year and may reduce the incidence of relapse. ${ }^{41}$ Prescribing information for varenicline is summarized in Table 5.

\section{Bupropion sustained release (SR)}

The proposed mechanisms of action of bupropion sustained release (SR) include the blockade of neuronal re-uptake of dopamine and norepinephrine. ${ }^{42}$ Similar to varenicline, bupropion SR

Table 5 Varenicline ${ }^{R x}$

\begin{tabular}{|c|c|}
\hline Product & $\begin{array}{l}\text { Chantix }^{\circledR} \text { (Pfizer, Inc., New York City, NY) } \\
\text { - } 0.5 \mathrm{mg} \text {, I mg tablet }\end{array}$ \\
\hline Precautions & $\begin{array}{l}\text { - Pregnancy } \\
\text { - May worsen pre-existing psychiatric illness } \\
\text { - Dosage adjustment required in patients with kidney } \\
\text { disease (creatinine clearance less than } 30 \mathrm{ml} / \mathrm{min} \text { ) or } \\
\text { who are on dialysis } \\
\text { - WARNING: Can cause depressed mood, agita- } \\
\text { tion, change in behavior, suicidal ideation, suicide. } \\
\text { Reported in patients attempting to quit smoking } \\
\text { while using varenicline. Monitor closely. }\end{array}$ \\
\hline Dosage & $\begin{array}{l}\text { Recommended: I-week titration: } \\
\text { Days I-3: } 0.5 \mathrm{mg} \text { tablet daily } \\
\text { Days 4-7: } 0.5 \mathrm{mg} \text { tablet BID (AM and HS) } \\
\text { Days 8+: I mg tablet BID (AM and HS) } \\
\text { - Set quit date } \\
\text { - Start one week before quit date } \\
\text { - Take after eating and with a full glass of water } \\
\text { - Nausea is dose related; if persistent and trou- } \\
\text { bling, consider dose reduction. Duration: I } 2 \text { wk; } \\
\text { if successful after I } 2 \text { week, an additional I } 2 \text { week } \\
\text { is recommended for increased likelihood of } \\
\text { long-term abstinence }\end{array}$ \\
\hline Side effects & $\begin{array}{l}\text { - Dose dependent nausea (most common) } \\
\text { - Insomnia } \\
\text { - Abnormal dreams } \\
\text { - Headache } \\
\text { - Dyspepsia } \\
\text { - Constipation } \\
\text { - Flatulence } \\
\text { - Vomiting }\end{array}$ \\
\hline Advantages & $\begin{array}{l}\text { - Provides nicotine effects to reduce withdrawal } \\
\text { symptoms and cravings } \\
\text { - Blocks the nicotine effects from smoking and } \\
\text { reduces reward of smoking } \\
\text { - May be used in those with cardiovascular disease } \\
\text { - No clinically meaningful drug interactions } \\
\text { - Found to be more effective than bupropion SR }\end{array}$ \\
\hline Disadvantages & $\begin{array}{l}\text { - Not studied in combination with other therapies } \\
\text { - Nausea associated with higher doses may be } \\
\text { bothersome } \\
\text { - Does not reduce weight gain } \\
\text { - May cause impaired ability to drive or operate heavy } \\
\text { machinery } \\
\text { - May cause neuropsychiatric symptoms including } \\
\text { behavioral changes, agitation, depressed mood, } \\
\text { suicidal ideation, and suicidal behavior }\end{array}$ \\
\hline
\end{tabular}

also carries an FDA warning for neuropsychiatric adverse events. Bupropion lowers the seizure threshold and is contraindicated in persons with a history of seizure disorder and those who are on other medications that lower the seizure threshold. ${ }^{3}$ It is also contraindicated in persons who have a prior or current history of eating disorder because of an increased risk for seizures. ${ }^{3}$ Bupropion SR is also an anti-depressant and like other anti-depressant drugs, it carries a warning for increased risk of suicidal ideation. Patients on bupropion should therefore be closely monitored for emerging neuropsychiatric symptoms and signs of suicidal ideation. Prescribing information for bupropion SR for smoking cessation is summarized in Table 6.

Table 6 Bupropion SR ${ }^{R x}$

\begin{tabular}{|c|c|}
\hline Product & $\begin{array}{l}\text { Zyban }^{\circledR} \text { (GlaxoSmithKline plc, Brentford, London, } \\
\text { England, UK), Generic } \\
\text { - I } 50 \text { mg sustained-release tablet }\end{array}$ \\
\hline Contraindications & $\begin{array}{l}\text { - History of seizure disorder } \\
\text { - History of stroke } \\
\text { - History of brain tumor, brain surgery, or serious } \\
\text { closed head injury } \\
\text { - Eating disorders } \\
\text { - Those taking another form of bupropion } \\
\text { - Monoamine oxidase inhibitor therapy within } \\
\text { previous } 14 \mathrm{~d} \\
\text { - Abrupt discontinuation of alcohol or } \\
\text { benzodiazepines at same time }\end{array}$ \\
\hline Precautions & $\begin{array}{l}\text { - Pregnancy } \\
\text { - Concomitant therapy with medications known to } \\
\text { lower the seizure threshold }\end{array}$ \\
\hline Dosage & $\begin{array}{l}\text { I50 mg PO q AM } \times 3 \mathrm{~d} \text {, then increase to } 150 \mathrm{mg} \\
\text { PO BID } \\
\text { - Treatment should be initiated while patient is } \\
\text { still smoking } \\
\text { - Set quit date I-2 weeks after initiation } \\
\text { - DO NOT exceed } 300 \mathrm{mg} / \mathrm{d} \\
\text { - Allow at least } 8 \mathrm{~h} \text { between doses } \\
\text { - Avoid bedtime dosing to minimize insomnia } \\
\text { - Can be used safely with NRT } \\
\text { - If progression towards abstinence unsuccessful } \\
\text { by week } 7, \text { discontinue } \\
\text { Duration: } 8-12 \text { wk, maintenance up to } 6 \text { months }\end{array}$ \\
\hline Side effects & $\begin{array}{l}\text { - Insomnia most common (35\%-40\%) } \\
\text { - Dry mouth } \\
\text { - Nervousness } \\
\text { - Agitation } \\
\text { - Anxiety } \\
\text { - Weight loss } \\
\text { - Constipation } \\
\text { - Seizures (risk is } 1 / 1000)\end{array}$ \\
\hline Advantages & $\begin{array}{l}\text { - Bupropion can be safely used with NRT } \\
\text { - Bupropion may be beneficial in patients with } \\
\text { depression } \\
\text { - No tapering required }\end{array}$ \\
\hline Disadvantages & $\begin{array}{l}\text { - Seizure risk is increased } \\
\text { - May increase the risk of suicidal thinking in } \\
\text { patients who have depression }\end{array}$ \\
\hline
\end{tabular}




\section{Nicotine replacement therapies}

Nicotine replacement therapy (NRT) drugs reduce craving and withdrawal symptoms by partially replacing lost nicotine intake. The main characteristics and prescribing information of available NRT products are summarized in Tables 7 through Table 11.,29,33-35,43,44

\section{Second-line medications}

Clonidine and nortriptyline are second-line medications used for smoking cessation. ${ }^{3,45}$ Although second-line medications have been shown to be effective in treating tobacco dependence, their use is limited mainly because of less favorable side-effect profile when compared to the first-line medications. Second-line medications are not approved by the FDA specifically for use in smoking cessation. ${ }^{3}$ Second-line medications should be considered for use on a case-by-case basis after first-line medications (either alone or in combination) have been used without success, or are contraindicated. ${ }^{3}$
Clonidine is contraindicated in pregnant women and in those who engage in potentially hazardous activities. The most common side effects of clonidine include dry mouth $(40 \%)$, drowsiness $(33 \%)$, dizziness $(16 \%)$, sedation $(10 \%)$ and constipation (10\%). ${ }^{3}$ Because abrupt discontinuation of clonidine can result in severe rebound hypertension, it should be tapered. Clonidine is available as $0.1 \mathrm{mg}, 0.2 \mathrm{mg}$, and $0.3 \mathrm{mg}$ scored tablets and $0.1 \mathrm{mg} / 24$ hours, $0.2 \mathrm{mg} / 24$ hours, and $0.3 \mathrm{mg} / 24$ hours transdermal patches. The usual dosage is $0.2 \mathrm{mg}-0.6 \mathrm{mg}$ per day in divided doses.${ }^{3,45}$ Specific dosage of clonidine for smoking cessation has not been established.

Nortriptyline is a tricyclic antidepressant and therefore carries an FDA warning about increased suicide risk. ${ }^{3}$ The most serious side effects of nortriptyline are arrhythmias and impairment of myocardial contractility. More common and less serious side effects include sedation, dry mouth, blurred vision, urinary retention, lightheadedness, and shaky hands. ${ }^{3}$ Nortriptyline is available as $10 \mathrm{mg}, 25 \mathrm{mg}, 50 \mathrm{mg}$, and $75 \mathrm{mg}$ capsules and $10 \mathrm{mg} / 5 \mathrm{~mL}$ liquid. The dosage of

Table 7 Transdermal Preparations ${ }^{\text {OTC/Rx }}$

\begin{tabular}{|c|c|c|c|}
\hline Products & & $\begin{array}{l}\text { Nicotrol Patch }{ }^{\circledR} \text { (McNeil Consumer Healthcare, } \\
\text { Fort Washington, PA) } \\
\text { - } 5 \mathrm{mg} \\
\text { - } 10 \mathrm{mg}, 15 \mathrm{mg} \text { (I6 hours) }\end{array}$ & $\begin{array}{l}\text { Nicoderm }{ }^{\circledR} \mathrm{CQ} \text { (Sanofi-Aventis S.A., Paris, } \\
\text { France); Generic nicotine patch } \\
\text { - } 7 \mathrm{mg} \\
\text { - } 14 \mathrm{mg}, 21 \mathrm{mg} \text { ( } 24 \text { hours) }\end{array}$ \\
\hline \multirow[t]{2}{*}{ Dosage } & $>10$ cigarettes/day & $\begin{array}{l}\text { - } 15 \mathrm{mg} / \text { day } \times 6 \text { week } \\
\text { - } 10 \mathrm{mg} / \text { day } \times 2 \text { week } \\
\text { - } 5 \mathrm{mg} / \text { day } \times 2 \text { week }\end{array}$ & $\begin{array}{l}\text { - } 21 \mathrm{mg} / \text { day } \times 6 \text { week } \\
\text { - } 14 \mathrm{mg} / \text { day } \times 2 \text { week } \\
\text { - } 7 \mathrm{mg} / \text { day } \times 2 \text { weeks }\end{array}$ \\
\hline & $\leq 10$ cigarettes/day & $\begin{array}{l}\text { - } 10 \mathrm{mg} / \text { day } \times 6 \text { week } \\
\text { - } 5 \mathrm{mg} / \text { day } \times 2 \text { week }\end{array}$ & $\begin{array}{l}\text { - I } 4 \mathrm{mg} / \text { day } \times 6 \text { week } \\
\text { - } 7 \mathrm{mg} / \text { day } \times 2 \text { week } \\
\text { - If }<100 \text { lbs or cardiovascular disease: } \\
\text { - } \text { I } 4 \mathrm{mg} / \text { day } \times 4-6 \text { week } \\
\text { - } 7 \mathrm{mg} / \text { day } \times 2-4 \text { week }\end{array}$ \\
\hline Comments $^{\mathrm{a}}$ & & $\begin{array}{l}\text { - Remove before bedtime } \\
\text { - Nicotine released over } 16 \mathrm{~h}\end{array}$ & $\begin{array}{l}\text { - May wear patch for } 24 \mathrm{~h} \\
\text { - Remove at bedtime if patient experiences sleep } \\
\text { disturbances. }\end{array}$ \\
\hline Contraindications & & \multicolumn{2}{|l|}{$\begin{array}{l}\text { - Recent ( } 2 \text { or less week post-myocardial infarctic } \\
\text { - Unstable angina pectoris } \\
\text { - Serious underlying arrhythmias }\end{array}$} \\
\hline Side effects & & \multicolumn{2}{|l|}{$\begin{array}{l}\text { - Local skin reactions: erythema, pruritis, burn } \\
\text { - Headache } \\
\text { - Sleep disturbances: insomnia, vivid dreams }\end{array}$} \\
\hline Advantages & & \multicolumn{2}{|c|}{$\begin{array}{l}\text { - Provides consistent nicotine levels over 16-24 hours } \\
\text { - Easy to use and conceal } \\
\text { - Fewer adherence issues } \\
\text { - Available without prescription }\end{array}$} \\
\hline Disadvantages & & \multicolumn{2}{|c|}{$\begin{array}{l}\text { - Patients cannot titrate the dose } \\
\text { - Allergic reactions to adhesive } \\
\text { - Patients with certain skin conditions cannot use patch } \\
\text { - Patch may contain aluminum }\end{array}$} \\
\hline
\end{tabular}

Notes: aPatch should be applied in the morning when patient wakes on the quit day. Apply on relatively hairless areas between the neck and waist. 
nortriptyline in smoking cessation studies ranges between $25 \mathrm{mg}$ per day and $100 \mathrm{mg}$ per day. ${ }^{3,45,46}$ Therapeutic drug level and cardiovascular monitoring, including electrocardiogram (ECG), is recommended.

Several investigators have reported on the use of iontophoresis and chemical enhancers to deliver nortriptyline

Table 8 Gum $^{\text {OTC }}$

Product

Nicorette ${ }^{\circledR}$ (GlaxoSmithKline plc, Brentford, London, England, UK), Nicorette DS ${ }^{\circledR}$ (GlaxoSmithKline plc, Brentford, London, England, UK), Generic

- $2 \mathrm{mg}, 4 \mathrm{mg}$; regular, mint, orange

Contraindications

- Pregnancy

- Recent ( $\leq 2$ weeks) myocardial infarction

- Serious underlying arrhythmias

- Serious or worsening angina pectoris

- Temporomandibular joint disease

Dosage

$\geq 25$ cigarettes/day: $4 \mathrm{mg}$

$<25$ cigarettes/day: $2 \mathrm{mg}$

Week I-6: I piece q I-2 hours

Week 2-4: I piece q 2-4 hours

Week 10-12: I piece q 4-8 hours

- Chew each piece slowly until peppery or flavored taste emerges

- Park between cheek and gum when tingling

- sensation appears

- Resume chewing when tingle fades

- Repeat chew/park steps until most of the nicotine is gone (taste or tingle does not return; generally 30 minutes)

- Park in different areas of mouth

- No food or beverages 15 minutes before or during use (acidic beverages reduce buccal absorption)

- If there are strong or frequent cravings, may use a 2 nd piece within the hour

Max: 24 pieces/day

Duration: Up to 12 week

Side effects

- Mouth soreness

- Throat irritation

- Jaw pain

- Hiccups

- Dyspepsia

- Hypersalivation

- Flatulence

- Nausea and vomiting

- Unpleasant taste

- Lightheadedness

Advantages

- Might satisfy oral cravings

- May delay weight gain

- Patients can titrate therapy to manage withdrawal symptoms

- Available over the counter

Disadvantages - Gum chewing may not be socially acceptable

- Difficult to use with dentures

- May cause loosening of dental fillings

- Patients must use proper chewing technique to minimize adverse effects and other smoking cessation agents transdermally. Escobar-Chavez and colleagues report that the controlled delivery of a chemical through the skin can be achieved by constant current iontophoresis. ${ }^{47}$ This involves the application of a small electrical potential and is unique to iontophoresis. The amount of compound delivered by iontophoresis is directly proportional to the quantity of charge passed, the current applied, the duration of current application, and the area of the skin surface in contact with the active electrode compartment. ${ }^{47}$ Melero and colleagues reported on results of their study on delivery of nortriptyline using iontophoresis. ${ }^{48}$ They noted that the highest flux obtained would provide the recommended doses for smoking cessation support therapy (25-75 mg) with a $2 \mathrm{~cm} \times 2 \mathrm{~cm}$ patch or $3.5 \mathrm{~cm} \times 3.5 \mathrm{~cm}$ patch, respectively, without skin damage. ${ }^{48}$ Merino and

Table 9 Lozenge ${ }^{\text {OTC }}$

\begin{tabular}{|c|c|}
\hline Product & $\begin{array}{l}\text { Commit }^{\circledR} \text { (GlaxoSmithKline plc, Brentford, London, } \\
\text { England, UK) } \\
\text { - } 2 \mathrm{mg}, 4 \mathrm{mg}\end{array}$ \\
\hline Contraindications & $\begin{array}{l}\text { - Pregnancy } \\
\text { - Recent ( } \leq 2 \text { weeks) myocardial infarction } \\
\text { - Serious underlying arrhythmias } \\
\text { - Serious or worsening angina pectoris }\end{array}$ \\
\hline Dosage & $\begin{array}{l}\text { Ist cigarette } \leq 30 \text { min after waking up: } 4 \mathrm{mg} \\
\text { I st cigarette }>30 \text { min after waking up: } 2 \mathrm{mg} \\
\text { Week I-6: I lozenge q I-2 hours; minimum } \\
9 \text { per day } \\
\text { Week 7-9: I lozenge q } 2-4 \text { hours } \\
\text { Week I0-I2: I lozenge q } 4-8 \text { hours } \\
\text { - Allow lozenge to dissolve slowly } \\
\text { (20-30 minutes ) } \\
\text { - Nicotine release may cause a warm or tingling } \\
\text { sensation } \\
\text { - Do not chew or swallow the lozenge } \\
\text { - Rotate the lozenge to different areas of the } \\
\text { mouth } \\
\text { - No food or beverages I } 5 \text { minutes before, during } \\
\text { or after use } \\
\text { - Do not use more than I lozenge at a time } \\
\text { Max: } 5 \text { lozenges every } 6 \text { h; } 20 \text { lozenges/day } \\
\text { Duration: up to I } 2 \text { week }\end{array}$ \\
\hline Adverse events & $\begin{array}{l}\text { - Nausea } \\
\text { - Hiccups } \\
\text { - Cough } \\
\text { - Heartburn } \\
\text { - Headache }\end{array}$ \\
\hline Advantages & $\begin{array}{l}\text { - Might satisfy oral cravings } \\
\text { - May delay weight gain } \\
\text { - Patients can titrate therapy to manage } \\
\text { withdrawal symptoms } \\
\text { - Provides } \sim 25 \% \text { more nicotine than gum } \\
\text { - Available over the counter }\end{array}$ \\
\hline Disadvantages & $\begin{array}{l}\text { - Gastrointestinal side effects might be bothersome } \\
\text { - Contains phenylalanine }\end{array}$ \\
\hline
\end{tabular}


Table I 0 Nasal spray ${ }^{R x}$

\begin{tabular}{|c|c|}
\hline Product & $\begin{array}{l}\text { Nicotrol NS }{ }^{\circledR} \text { (Pfizer, Inc., New York City, NY) } \\
\text { - Metered spray (0.5 mg nicotine/actuation) aqueous } \\
\text { nicotine }\end{array}$ \\
\hline Contraindications & $\begin{array}{l}\text { - Pregnancy } \\
\text { - Recent ( } \leq 2 \text { weeks) myocardial infarction } \\
\text { - Serious underlying arrhythmias } \\
\text { - Serious or worsening angina pectoris }\end{array}$ \\
\hline Dosage & $\begin{array}{l}\text { I-2 doses/h ( } 8-40 \text { doses/day) } \\
\text { One dose: } 2 \text { sprays (one in each nostril); each spray } \\
\text { delivers } 0.5 \mathrm{mg} \text { of nicotine to the nasal mucosa } \\
\text { - Patients should not sniff, swallow, or inhale } \\
\text { through the nose as the spray is administered } \\
\text { - For best results, initially use at least } 8 \text { doses/day } \\
\text { - DO NOT exceed } 5 \text { doses/hours and } \\
40 \text { doses/ day } \\
\text { - Gradually decrease usage } \\
\text { Duration (maximal): } 3 \text { month }\end{array}$ \\
\hline Side effects & $\begin{array}{l}\text { - Nasal and throat irritation (hot, peppery, or } \\
\text { - trarning sensation) } \\
\text { - Rhinitis } \\
\text { - Tearing } \\
\text { - Sneezing } \\
\text { - Cough } \\
\text { - Headache } \\
\text { - Nausea }\end{array}$ \\
\hline Advantages & $\begin{array}{l}\text { - Patients can easily titrate therapy to rapidly } \\
\text { manage withdrawal symptoms } \\
\text { - Fastest acting nicotine product }\end{array}$ \\
\hline Disadvantages & $\begin{array}{l}\text { - Nasal/throat irritation may be bothersome } \\
\text { - Dependence can result } \\
\text { - Patients must wait } 5 \text { minutes before driving or } \\
\text { operating heavy machinery } \\
\text { - Patients with chronic nasal disorders (allergy, } \\
\text { rhinitis, nasal polyps, or sinusitis) or severe reactive } \\
\text { airway disease should NOT use the spray } \\
\text { - No optimal tapering schedule } \\
\text { - Prescription only }\end{array}$ \\
\hline
\end{tabular}

colleagues reported on the use of chemical enhancers and ionotphoresis to enhance transdermal delivery of nortriptyline. ${ }^{49}$ They also noted that iontophoresis could be used to provide therapeutic concentrations of the drug in smoking cessation treatment.

\section{Conclusion}

Tobacco use remains a great public health concern, especially in adolescents. The significant health hazards of smoking and other forms of tobacco use are well-documented. Smoking can also adversely affect exercise and sports performance. Tobacco addiction is primarily caused by nicotine, though other chemicals contained within tobacco products are now believed to play a secondary role in addiction. A combined behavioral and pharmacological approach has been found to
Table I I Oral inhaler ${ }^{R x}$

\begin{tabular}{|c|c|}
\hline Product & $\begin{array}{l}\text { Nicotrol Inhaler }{ }^{\circledast} \text { (Pfizer, Inc., New York City, NY) } \\
\text { - I0 mg cartridge delivers } 4 \text { mg inhaled nicotine } \\
\text { vapor }\end{array}$ \\
\hline Contraindications & $\begin{array}{l}\text { - Pregnancy } \\
\text { - Recent ( } \leq 2 \text { weeks) myocardial infarction } \\
\text { - Serious underlying arrhythmias } \\
\text { - Serious or worsening angina pectoris }\end{array}$ \\
\hline Dosage & $\begin{array}{l}\text { 6-16 cartridges/d; individualize dosing } \\
\text { - Initially, use at least } 6 \text { cartridges/d for first } \\
3-6 \text { week } \\
\text { - Best effects with continuous puffing for } \\
20 \text { minutes } \\
\text { - Nicotine in cartridge is depleted after } \\
20 \text { minutes of active puffing (oral inhalation) } \\
\text { - Patients should inhale deeply into back of throat } \\
\text { or puff in short breaths } \\
\text { - Open cartridge retains potency for } 24 \text { hours } \\
\text { - Each cartridge delivers } 4 \text { mg of nicotine over } 80 \\
\text { inhalations } \\
\text { - Avoid eating or drinking for } 15 \text { minutes } \\
\text { before and after use (acidic beverages reduce } \\
\text { absorption) } \\
\text { Duration:Treat for } 3 \text { month and then taper over } \\
\text { next } 3 \text { month }\end{array}$ \\
\hline Adverse events & $\begin{array}{l}\text { - Mouth and throat irritation (40\%) } \\
\text { - Unpleasant taste } \\
\text { - Cough }(32 \%) \\
\text { - Rhinitis }(23 \%) \\
\text { - Dyspepsia } \\
\text { - Headache }\end{array}$ \\
\hline Advantages & $\begin{array}{l}\text { - Patients can easily titrate therapy to rapidly man- } \\
\text { age withdrawal symptoms } \\
\text { - The inhaler mimics hand-to-mouth ritual of } \\
\text { smoking }\end{array}$ \\
\hline Disadvantages & $\begin{array}{l}\text { - Initial throat or mouth irritation can be } \\
\text { bothersome } \\
\text { - Dependence can occur } \\
\text { - Cold temperatures }\left(<60^{\circ} \mathrm{F}\right) \text { reduce amount of } \\
\text { nicotine delivered } \\
\text { - Avoid hot environments }\left(>77^{\circ} \mathrm{F}\right) \text { and protect } \\
\text { from light } \\
\text { - Patients with underlying bronchospastic disease } \\
\text { must use with caution } \\
\text { - No definitive tapering schedule } \\
\text { - Prescription only }\end{array}$ \\
\hline
\end{tabular}

be more effective for smoking cessation than either approach used alone. The importance of team effort in any smoking cessation strategy should be recognized. The environmental factors and public policies play important roles in population wide smoking cessation efforts. Considerable evidence supports the role of the pharmacist in the management of chronic diseases, including smoking cessation. To decrease the overall burden of smoking, all healthcare practitioners need to work together. A range of pharmacological agents and behavioral therapies are available for smoking cessation. 
Varenicline, bupropion SR, and nicotine replacement therapies are recommended as first-line drugs for smoking cessation. In selected cases the first-line drugs may also be used in combination with each other to improve outcomes. Treatment interventions have been shown to double the rate of smoking cessation when compared to quit attempts without intervention. Tobacco dependence should be considered a chronic disease with anticipated relapses requiring long-term monitoring and treatment.

\section{Acknowledgments}

Authors thank Kim Douglas for assistance with the preparation of this manuscript. Data in Table 5 to Table 11 are derived from: 1) Fiore MC, Jaen CR, Baker TB, et al Treating Tobacco Use and Dependence 2008 Update. Clinical Practice Guideline. Rockville, MD: US Department of Health and Human Services. Public Health Service. May 2008; 2) Food and Drug Administration product information available at www.fda.gov; 3) Drug manufacturer product labels available at manufacturer web sites; including following web sites:

Chantix http://www.accessdata.fda.gov/drugsatfda_docs/ label/2008/021928s007lbl.pdf; Zyban http://www.fda. gov/Safety/MedWatch/SafetyInformation/ucm176815.htm; Nicotrol inhaler http://media.pfizer.com/files/products/uspi_ nicotrol_inhaler.pdf; Nicotrol NS http://media.pfizer.com/ files/products/uspi_nicotrol.pdf; Nicoderm CQ http://www. nicodermcq.com/; Commit http://www.commitlozenge.com/; Nicorette http://www.nicorette.com/

\section{Disclosures}

The authors report no conflicts of interest that are relevant to this research.

\section{References}

1. Britannica.com (Encyclopaedia Britannica). http://www.britannica. com. Accessed August 16, 2009.

2. Centers for Disease Control and Prevention. Smoking and tobacco use: fact sheets. Available at http://www.cdc.gov/tobacco/data_statistics/ fact_sheets. Accessed August 11, 2009.

3. Fiore MC, Jaen CR, Baker TB, et al. Treating Tobacco Use and Dependence 2008 Update. Clinical Practice Guideline. Rockville, MD: US Department of Health and Human Services. Public Health Service; 2008.

4. US Department of Health and Human Services. National Institute of on Drug Abuse. Research Report Series: Tobacco Addiction. Available from: http://www.nida.hih.gove/reserachreports/nicotine/nicotine.html. Accessed August 17, 2009.

5. World Health Organization. WHO Report on the Global Tobacco Epidemic, 2008. Geneva, Switzerland: WHO; 2008.

6. Hatsukami DK, Stead LF, Gupta PC. Tobacco addiction. Lancet. 2008;371(9629):2027-2038.
7. Benowitz NL. Pharmacology of nicotine: addiction, smoking-induced disease, and therapeutics. Annu Rev Pharmacol Toxicol. 2009;49: $57-71$.

8. Walsh MM, Ellison J, Hilton JF, Chesney M, Ernster VL. Spit (smokeless) tobacco use by high school baseball athletes in California. Tob Control. 2009;9 Suppl 2:ii32-ii39.

9. Melnick MJ, Miller KE, Sabo DF, Farrell MP, Barnes GM. Tobacco use among high school athletes and nonatheletes: results of the 1997 youth risk behavior survey. Adolescence. 2001;36(144):727-747.

10. Green GA, Uryasz FD, Petr TA, Bray CD. NCAA study of substance use and abuse habits of college student-athletes. Clin J Sport Med. 2001;11(1):51-56.

11. Alaranta A, Alaranta H, Patja K, Palmu P, Prättälä R, Martelin T, Helenius I. Snuff use and smoking in Finnish Olympic athletes. Int J Sports Med. 2006;27(7):581-586.

12. Peretti-Watel P, Guagliardo V, Verger P, Pruvost J, Mignon P, Obadia Y. Sporting activity and drug use: alcohol, cigarette and cannabis use among elite student athletes. Addiction. 2003;98(9):1249-1256.

13. Walsh MM, Hilton JF, Ernster VL, Masouredis CM, Grady DG. Prevalence, patterns, and correlates of spit tobacco use in a college athlete population. Addict Behv. 1994;19(4):411-427.

14. Davis TC, Arnold C, Nandy I, Bocchini JA, Gottlieb A, George RB, Berkel H. Tobacco use among male high school athletes. J Adolesc Health. 1997;21(2):97-101.

15. Epps RP, Lynn WR, Manley MW. Tobacco, youth, and sports. Adolesc Med. 1998;9(3):483-490.

16. United State Food and Drug Administration. Electronic cigarettes. Available from: http://www.fda.gov. Accessed January 1, 2010.

17. Wollinscheid KA, Kremzner ME. Electronic cigarettes: safety concerns and regulatory issues. Am J Health Sys Pharm. 2009;66(19): $1740-1742$.

18. Fletcher PJ, Lê AD, Higgins GA. Serotonin receptors as potential targets for modulation of nicotine use and dependence. Prog Brain Res. 2008; 172:361-383.

19. Gamberino WC, Gold MS. Neurobiology of tobacco smoking and other addictive disorders. Psychiatic Clin North Am. 1999;22:301-312.

20. Rose JE. Disrupting nicotine reinforcement: from cigarette to brain. Ann N Y Acad Sci. 2008;1141:233-256.

21. Taylor P. Agents acting at the neuromuscular junction and autonomic ganglia. In: Hardman JG, Limbird LE, editors. Goodman Gilman's The Pharmacologic Basis of Therapeutics, 9th ed. New York, NY: McGrawHill, 1996. p. 177-198.

22. US Department of Health and Human Services. The Health Consequences of Smoking. Nicotine Addiction: A Report of the Surgeon General. Washington, DC; US Departament of Health and Human Services; 1988.

23. Aubry M, Wright JL, Myers JL. The pathology of smoking-related diseases. Clin Chest Med. 2000;21:11-35.

24. Fiore MC, Piaseck TH, Baker LJ, Decren SM. Cigarette smoking: the leading preventable cause of pulmonary disease. In: Bone RC, editors: Pulmonary and Critical Care Medicine. St. Louis, Mosby MO: 1998.

25. Patel DR, Homnick DN. Pulmonary effects of smoking. Adolesc Med. 2000; 11:547-565.

26. Sethi JM, Rochester CL. Smoking and chronic obstructive pulmonary disease. Clin Chest Med. 2000;21(1):67-86.

27. US Department of Health and Human Services. The Health Consequences of Smoking: A Report of the Surgeon General. Atlanta, GA: US Department of Health and Human Services, CDC, National Center for Chronic Disease Prevention and Health Promotion, Office of Smoking and Health; 2004. Available from http://www.cdc,gov/tobacco/data_statistics/sgr/sgr_2004/index.htm. Accessed August 11, 2009.

28. US Department of Health and Human Services. The Health Benefits of Smoking Cessation: A Report of the Surgeon General. 1990 Washington, DC; US Department of Health and Human Services. Available from: http://www.cdc.gov/tobacco/data statistics/ sgr/index.htm.

29. Smith SS, McCarthy DE, Japuntich SJ, et al. Comparative effectiveness of 5 smoking cessation pharmacotherapies in primary care clinics. Arch Intern Med. 2009;169(22):2148-2155. 
30. Lemmens V, Oenema A, Knut IK, Brug J. Effectiveness of smoking cessation interventions among adults: a systematic review of reviews. Eur J Cancer Prev. 2008;17(6):535-544.

31. Garrison GD, Dugan SE. Varenicline: a first-line treatment option for smoking cessation. Clin Ther. 2009;31(3):463-491.

32. Shah SD, Wilken LA, Winkler SR, Lin SJ. Systematic review and meta-analysis of combination therapy for smoking cessation. $\mathrm{J} \mathrm{Am}$ Pharm Assoc. 2008;48(5):659-665.

33. Carrozzi L, Pistelli F, Viegi G. Pharmacotherapy for smoking cessation. Ther Adv Respir Dis. 2008;2(5):301-317.

34. Eisenberg MJ, Filion KB, Yavin D, et al. Pharmacotherapies for smoking cessation: a meta-analysis of randomized controlled trials. CMAJ. 2008;179(2):135-144. Review. Erratum in: CMAJ. 2008;179(8):802.

35. Fant RV, Buchhalter AR, Buchman AC, Henningfield JE. Pharmacotherpay for tobacco dependence. Handb Exp Pharmacol. 2009;192:487-510.

36. The Medical Letter: Drugs for tobacco dependence. Treatment Guidelines The Medical Letter. 2008;6(73):61-66.

37. Hajeck P, Stead LF, West R, Jarvis M, Lancaster T. Relapse prevention interventions for smoking cessation. Cochrane Database Syst Rev. 2009(1):CD003999.

38. Galanti LM. Tobacco smoking cessation management: integrating varenicline in current practice. Vasc Health Risk Manag. 2008;4(4):837-845.

39. Garrison GD, Dugan SE. Varenicline: a first-line treatment option of smoking cessation. Clin Ther. 2009;31(3):463-491.

40. Hays JT, Ebbert JO. Varenicline for tobacco dependence. N Eng J Med. 2008;359(19):2018-2024.

41. Lee JH, Jones PG, Bybee K, O’Keefe JH. A longer course of varenicline therapy improves smoking cessation rates. Prev Cardiol. 2008;11(4):210-214.
42. Paterson NE. Behavioural and pharmacological mechanisms of bupropion's anti-smoking effects: recent preclinical and clinical insights. Eur J Pharmacol. 2009;603(1-3):1-11. Epub 2008 Dec 16.

43. Walsh RA. Over-the-counter nicotine replacement therapy: a methodological review of the evidence supporting its effectiveness. Drug Alcohol Rev. 2008;27(5):529-547.

44. Amodei N, Lamb RJ. Over-the-counter nicotine replacement therapy: can its impact on smoking cessation be enhanced? Psychol Addict Behav. 2008;22(4):472-485.

45. Stahl SM. Essential Psychopharmacology: A Prescriber's Guide, New York; Cambridge University Press, 2006. p. 53-58. p. 353-360.

46. Hughes JR, Stead LF, Lancaster T. Antidepressants for smoking cessation. Cochrane Database Syst Rev. 2007;24(1):CD0000311.

47. Escobar-Chavez JJ, Merino V, Lopez-Cervantes M, Rodriguez-Cruz IM, Quintanar-Guerrero D, Ganem-Quintanar A. The use of iontophoresis in the administration of nicotine and new non-nicotine drugs through the skin for smoking cessation. Curr Drug Discov Technol. 2009;6(3):171-185.

48. Melero A, Garrigues TM, Alos M, Kostka KH, Lehr CM, Schaefer UF. Nortriptyline for smoking cessation: release and human skin diffusion from patches. Int J Pharm. 2009;378(1-2):101-107.

49. Merino V, Mico-Albinana T, Nacher A, Diaz-Sales O, Herraez M, Merino-Sanjuan M. Enhancement of nortriptyline penetration through human epidermis: influence of chemical enhancers and iontophoresis. J Pharm Pharmacol. 2008;60(4):415-420.
Clinical Pharmacology: Advances and Applications

\section{Publish your work in this journal}

Clinical Pharmacology: Advances and Applications is an international, peer-reviewed, open access journal publishing original research, reports, reviews and commentaries on all areas of drug experience in humans. The manuscript management system is completely online and includes a very quick and fair peer-review system, which is all easy to use.

\section{Dovepress}

Visit http://www.dovepress.com/testimonials.php to read real quotes from published authors. 